\title{
Climatic and morphological control of rare earth element distribution in weathering mantles on alkaline rocks
}

\author{
Andreas Marker and Joaquim Julio de Oliveira \\ Instituto de Geociencias, UFBa, 40000 Salvador, Bahia, Brazil
}

\begin{abstract}
In humid coastal regions and in areas of accentuated relief of SE-Bahia, Brazil, weathering of alkaline rocks resulted in the formation of kaolinitic and lateritic weathering mantles. Under subhumid conditions in the inland region of Bahia, less mature sandy-clayey soil have developed. Rare Earth Element (REE) distribution in the weathering profiles has been investigated in order to establish relationships between climatic and morphological parameters and the enrichment and fractionation of REE. Under tropical humid climate and intensive drainage conditions, REE fractionation is enhanced. Ce is absolutely enriched in laterite layers while the Heavy REE are retained in the saprolite. Moderate drainage due to high groundwater tables lead to minor fractionation and enrichment of REE. Restricted drainage conditions in subhumid climatic zones hamper liberation of REE from primary minerals and impede enrichment and fractionation of these elements. REE distribution is also controlled by polyphase evolution of the weathering mantle: the positive Ce anomalies in laterite layers are related to stable mineral phases like Mn oxides, which have developed in roots of weathering during former, less humid weathering cycles.

The REE fractionation patterns correspond to the drainage conditions which prevailed during the formation of the weathering products. Thus they may represent a valuable tool for the reconstruction of landscape evolution and the investigation of the paleoenvironment.
\end{abstract}

\section{Introduction}

Tropical weathering of alkaline rocks in Brazil results in the formation of extensive weathering mantles. Humid tropical climate and moderate relief favour bauxitisation and lateritisation, representing the end product of lateritic weathering under good drainage conditions. Less intensive drainage with restricted removal of silica, alkali and earth alkali elements may lead to the formation of fersiallitic and bisiallitic, sandy clayey weathering products.

The spatial distribution of bauxites, laterites and fersiallitic soils in Brazil does not 
necessarily correspond to the actual climatic conditions. The formation of bauxites in South-Brazil like e.g. in Poços de Caldas, Itatiaia, Passa Quatro and Lages are related to more humid climatical conditions in the past (Melfi and Carvalho, 1983). On the other hand, kaolinitic weathering products with no indications of bauxitisation have developed on alkaline rocks in tropical humid zones like São Sebastião Island near Rio de Janeiro (Kronberg et al., 1987).

Thus the evolution of weathering mantles on alkaline rocks in Brazil in most of the cases represents the result of polyphase and polygenetic weathering processes. Drainage conditions which control the geochemical and mineralogical composition of weathering products are intimately related to climatic and morphological parameters. Thus the interpretation of geochemical and mineralogical patterns in weathering material, especially the investigation of Rare Earth Elements (REE) may yield direct evidence on climatic and morphological control of profile evolution, on paleoclimatic conditions and on landscape evolution.

Regarding the supergene fractionation and enrichment of REE, the until now obtained results still diverge significantly, especially in respect to the behaviour of individual REE like Ce and groups like the Heavy REE (HREE) (Trescases et al., 1987; Bonnot-Courtois, 1981; Braun et al., 1990). The divergence may be due to the fact that investigations of isolated REE ocurrences in individual profiles usually lack integration into a more regional or global scale.

This contribution focuses on the interpretation of REE patterns on a regional scale by comparing profiles from varios climatic zones and morphological positions. Under consideration of polyphase and polygenetic weathering processes, present REE distribution patterns are related to different phases of landscape and climatic evolution in SE-Bahia State, Brazil. Finally the use of REE patterns as tools for the reconstruction of landscape evolution and weathering history is discussed.

\section{Geological and geographical setting}

In the study area various intrusions of alkalic silicate rocks of syenitic and nepheline-syenitic composition are hosted in granulitic and gneissic rocks of the Archean basement (Fig. 1). The alkaline rocks have radiometric ages between 430 and 770 ma (Cordani et al., 1974). From NE to SW, the alkaline bodies consist mainly of nepheline--aegirine syenites, syenites and monzonites (Itabuna), sodalite syenites (Sta. Cruz), quartz syenites (Potiragua) and syenites and monzonites (Itarantim). Main mineralogical components are microcline, albite and microperthite, nepheline and sodalite. Mafic minerals are arfvedsonite, aegirine augite and biotite. Apatite, sphene, zircon and allanite represent the most important REE-bearing accessory minerals. The REE fractionation patterns of the alkaline rocks show a distinct dominance of the Light REE (LREE). La/Lu ratios vary between 26 and 352 with a mean value of 183 (Marker, 1991).

Within the study area various climatic zones can be differentiated (Fig. 1). Profiles 21,22 and 23 are located in the humid coastal zone which is characterized by hydrological exess rates. Principal morphological features are rolling hills with 


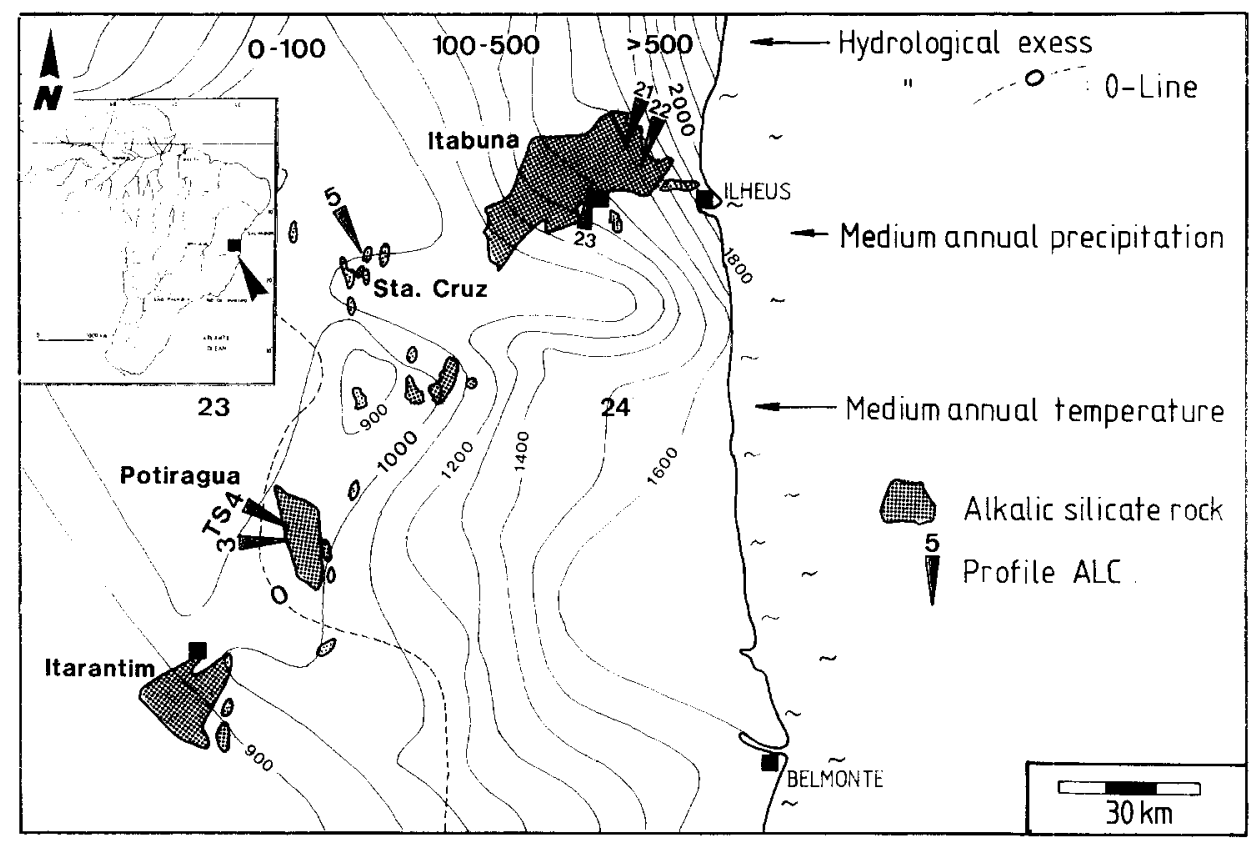

Fig. 1. Sketch map of the study area and climatological parameters.

elevations between 100 and $150 \mathrm{~m}$. In this region tropical rainforest vegetation is almost entirely preserved. Profile 5 and $5 \mathrm{~A}$ are situated in a climatic zone with annual precipitation of around $1100 \mathrm{~mm}$. The topography is mountainous and patches of tropical rainforest alternate with grassland vegetation. Profile 3 and profile sequence 4 (TS 4) are located in the subhumid climatic zone of the inland region of Bahia. The landscape is characterized by gently rolling mountain plateaus with intramontanous depressions.

\section{The weathering products}

\subsection{Classification and description of weathering products}

The weathering mantle on alkaline rocks in SE-Bahia consists of loose friable reddish-brown latosols (Profile 5, 22) or sandy-clayey soils (Profile 3, TS 4, 21, 23).

In the classification scheme for lateritic weathering products after Schellmann (1982), the majority of the weathering products above alkaline rocks in SE-Bahia has hardly attained the stage of kaolinisation (Fig. 2). With the exception of the uppermost laterite layer of profile 22 and the sandy-clayey soils from profiles 3 and TS 4, which show low maturity, the recent weathering conditions in the more humid regions of SE Bahia lead to kaolinisation. This fact is supported by thermodynamic calculations of the water-mineral equilibrium (Fig. 3). The groundwater composition of profile 22 is in equilibrium conditions with kaolinite in respect to the main rock forming minerals. 


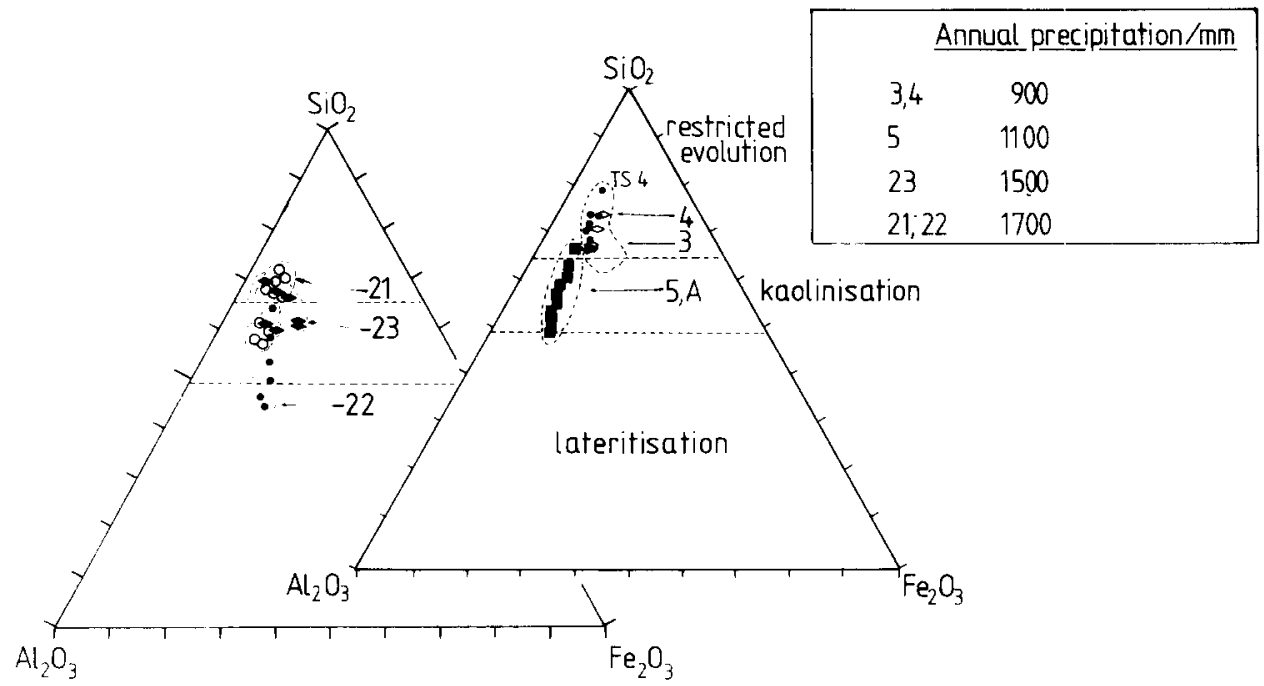

Fig. 2. Classification of weathering products on alkali ne bedrock from SE-Bahia after Schellmann (1982).

Latosol profiles consist of a reddish-brown kaolinite and goethite rich upper horizon, containing minute, blackish-brown concretions in its topmost portion and concretionary fissures in its lower part, grading towards depth into a yellowish brown-red saprolite with preservation of rock structures. In inclined hillslope position (profile 5), the saprolite is extremely thin $(<30 \mathrm{~cm}$ ) with sharp contact towards the underlying sodalite syenite bedrock. In hilltop position (profile 5A)

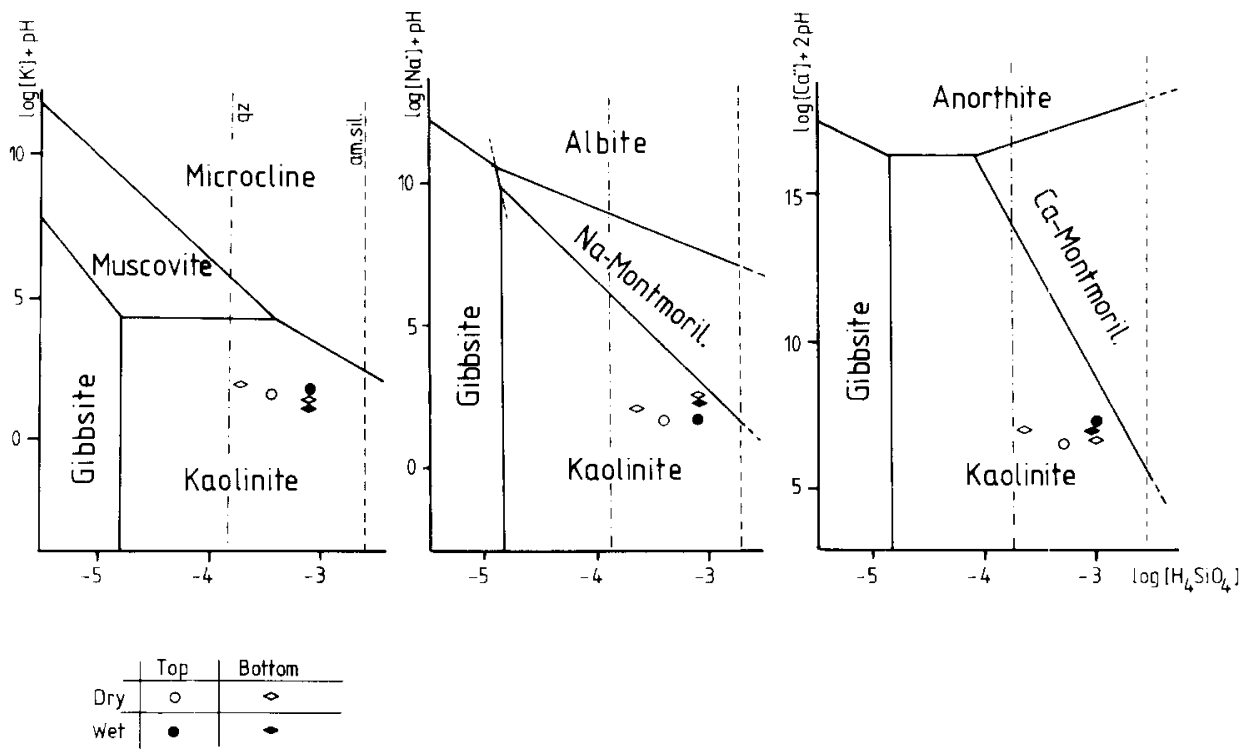

Fig. 3. Groundwater composition in the area of profile 22 and stability fields of primary and secondary minerals. top $=$ hillslope, bottom $=$ hillfoot, wet $=$ after rain, dry $=$ before rain . 
and along gentle hillslopes close to the groundwater table (profile 22), the saprolites are thick and may contain boulders of unweathered bedrock. Here the transition to the underlying bedrock is gradual.

The relatively thin soil profiles consist of yellowish grey-brown sandy-clayey soil horizons with thicknesses less than $3 \mathrm{~m}$. The material is friable, containing minute blackish brown nodular concretions in upper parts of the horizon (TS 4). In profile 3 , 21 and 23, the soil horizons are underlain by a rather hard and compact saprolite which grades towards depth into fresh bedrock. Along toposequence TS 4 , the hilltop profiles consist of a $20-40 \mathrm{~cm}$ thick indurated, blackish brown, spongycellular crust, grading towards depth into a sandy-clayey horizon and a thin saprolite. Along the hillslope, the profile consists of a sandy-clayey top horizon with nodular blackish brown concretions, grading towards depth into a yellowish brown saprolite.

Locally the lowermost portion of the saprolite is highly indurated resulting from cementation by secondary silica. This portion of the saprolite has the appearance and consistency of white sandstone. Here the contact to the fresh bedrock is rather sharp.

Thicknesses of the individual profile layers, $\mathrm{pH}$ values and bedrock composition are shown in Fig. 4.

\subsection{Geochemical and mineralogical evolution}

The weathering products show different stages of depletion of alkalis and Si. In sequence $\mathrm{Ca}$ is the first element to be depleted, followed by $\mathrm{Mg}, \mathrm{Na}$ and $\mathrm{K}$ (Fig. 4).

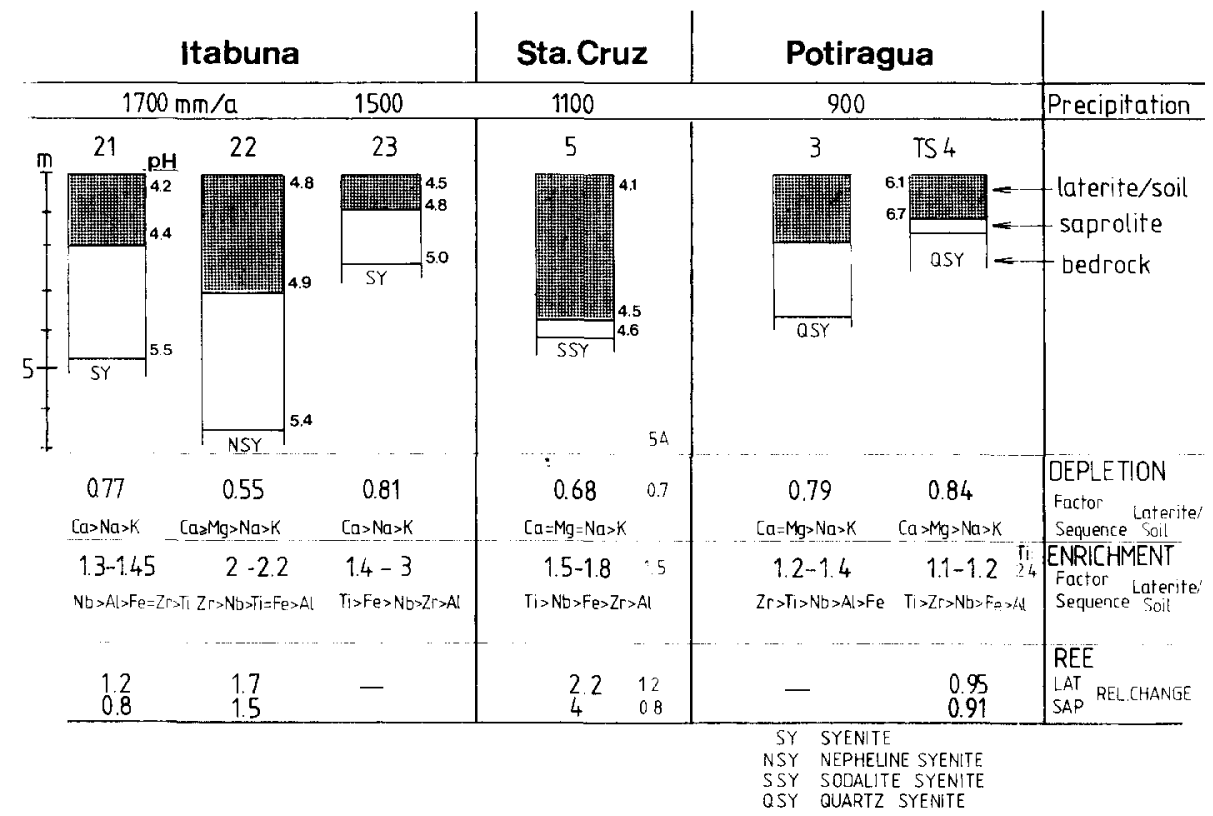

Fig. 4. Geochemical, pedological and climatological para meters of weathering of alkaline rocks in SEBahia. 
This corresponds to the sequence of mineral dissolution: calcite, followed by mafic minerals, feldspathoids, albite and finally microcline.

The depletion factor was calculated as the sum of alkali + earth alkali + Si contents in the latosol or soil horizon divided by the contents of these elements in the corresponding fresh bedrocks of the profiles. It can be regarded as an indicator for drainage conditions and profile maturity ("Depletion Factor" in Fig. 4). The most advanced depletion is observed in the well drained latosol profiles 5 and 22 with factors of 0.68 and 0.55 , indicating that the laterite only preserves $68 \%$ respectively $55 \%$ of the primary alkali- and $\mathrm{Si}$ concentration of the bedrock. Correspondingly the factors of residual enrichment of the less mobile elements, calculated from the mean enrichment factors of $\mathrm{Fe}, \mathrm{Nb}, \mathrm{Ti}, \mathrm{Zr}$ and - with restricton of TS 4 - also of $\mathrm{Al}$ in the latosol or soil horizon in relation to bedrock, are highest in profiles 5 and 22 ("Enrichment Factor" in Fig. 4). The enrichment sequence of these elements indicate that most of the heavy minerals like ilmenite, rutile, sphene ( $\mathrm{Ti})$ and zircon $(\mathrm{Zr})$ are rather stable. $\mathrm{Fe}$ in general shows residual behaviour whereas $\mathrm{Al}$ is partly mobilized, especially in TS 4 . This fact has been proven by mass balance calculations (Marker, 1991).

Less intensive drainage in profile 21 and 23 of Itabuna is related to the morphological position of these profiles, which are located in lowland areas with a high groundwater table.

Low maturity in function of climatically controlled drainage deficiencies characterize the sandy-clayey soils of Potiragua. Precipitation of secondary silica due to seasonal $\mathrm{Si}$-supersaturation in weathering solutions can locally be observed. Clay mineral lessiviation from the eluvial top horizon to the illuvial bottom horizon of the profiles of TS 4 is common. Depletion factors between 0.79 and 0.84 reveal that $79 \%$ to $84 \%$ of the rock forming felspar minerals and feldspathoids have not been hydrolyzed.

\subsection{REE distribution}

\subsubsection{Enrichment and fractionation relative to bedrock}

The relative enrichment of REE in the weathering products in relation to bedrock is most pronounced in the well drained profiles 5 and 22 (Table 1, Figs. 5 and 6). High REE concentrations and positive $\mathrm{Ce}$ anomalies can be found in the laterite layers where REE are mainly bound to manganiferous concretions, fissure fillings (profile 22) and pisolites (profile 5) (Figs. 5 and 6). In profile 5, REE are locally concentrated in the thin saprolite zone bound to vermiculite and hydrobiotite (Fig. 5A) (Marker, 1991).

The fractionation patterns normalized to bedrock indicate that the laterite layers preserve distinct enrichment of the LREE $\mathrm{La}-\mathrm{Gd}$, whereas the HREE are depleted. The REE fractionation in the saprolites has a contrary trend with relative enrichment of the HREE and absence of positive $\mathrm{Ce}$ anomalies. The exceptional $\mathrm{Ce}$ anomaly in the saprolite of profile 5 is of local importance. In the saprolite zone of the neighbouring profile $5 \mathrm{~A}$, situated in hilltop position, a distinct negative $\mathrm{Ce}$ anomaly can be identified (Fig. 5B). 
Table 1

Contents of Rare Earth Elements (in ppm) of weathering products and related bedrocks (numbers with $9 \ldots$ )

\begin{tabular}{|c|c|c|c|c|c|c|c|c|c|c|c|c|}
\hline Sample & REEtot & $\mathrm{La}$ & $\mathrm{Ce}$ & $\mathrm{Nd}$ & $\mathrm{Sm}$ & $\mathrm{Eu}$ & $\mathrm{Gd}$ & Dy & Ho & Er & $\mathrm{Yb}$ & $\mathrm{Lu}$ \\
\hline \multicolumn{13}{|c|}{ Profile $4 A^{\prime \prime}$} \\
\hline 421 & 258 & 38.9 & 167.1 & 34.9 & 5.6 & 2.1 & 3.5 & 3 & 0.6 & 1.3 & 1.1 & 0.14 \\
\hline 422 & 305 & 58.5 & 164.9 & 55 & 8.6 & 3.3 & 5.5 & 4.6 & 0.8 & 1.9 & 1.5 & 0.19 \\
\hline 423 & 338 & 67.7 & 174.2 & 64.4 & 10.3 & 3.7 & 6.7 & 5.5 & 1 & 2.3 & 1.8 & 0.22 \\
\hline 424 & 396 & 75.8 & 202.7 & 78.3 & 12.4 & 4.6 & 8.2 & 7.1 & 1.3 & 3.2 & 2.4 & 0.29 \\
\hline 425 & 352 & 71 & 168.7 & 78.2 & 12.7 & 4.6 & 7.5 & 5.4 & 0.9 & 1.8 & 1.2 & 0.15 \\
\hline $947: 8$ & 297 & 55.5 & 119 & 73.8 & 13.6 & 5 & 9.6 & 9.7 & 1.8 & 4.8 & 3.9 & 0.50 \\
\hline \multicolumn{13}{|c|}{ Profile 5} \\
\hline 51 & 412 & 112 & 219 & 55.6 & 7.7 & 2.56 & 4.86 & 3.69 & 0.62 & 1.86 & 2.62 & 0.42 \\
\hline 53 & 261 & 75.5 & 147.3 & 26 & 3.3 & 1.08 & 2.84 & 1.88 & 0.27 & 0.75 & 1.34 & 0.22 \\
\hline 54 & 255 & 80.2 & 129.2 & 31.8 & 3.8 & 1.31 & 3.2 & 2.34 & 0.39 & 0.89 & 1.53 & 0.26 \\
\hline 55 & 558 & 111.4 & 382.2 & 47.7 & 4.7 & 1.88 & 4.84 & 2.56 & 0.37 & 1.03 & 1.19 & 0.14 \\
\hline 956 & 141 & 42.35 & 66.1 & 24 & 2.5 & 1.18 & 1.86 & 1.5 & 0.25 & 0.61 & 0.74 & 0.12 \\
\hline \multicolumn{13}{|c|}{ Profile $5 \mathrm{~A}$} \\
\hline 352 & 559 & 161.7 & 268 & 91.8 & 12.8 & 3.6 & 7.2 & 6 & 1.2 & 3.3 & 3.2 & 0.4 \\
\hline 354 & 322 & 97 & 154.8 & 49.6 & 6.5 & 1.9 & 3.9 & 3.3 & 0.7 & 1.8 & 1.8 & 0.25 \\
\hline 356 & 255 & 90.8 & 105 & 43 & 5.4 & 1.5 & 3 & 2.6 & 0.5 & 1.5 & 1.3 & 0.18 \\
\hline 358 & 182 & 68.6 & 68.3 & 32.8 & 4.1 & 1.3 & 2.3 & 2 & 0.4 & 1.1 & 1 & 0.13 \\
\hline 360 & 319 & 110 & 133.2 & 54.7 & 6.8 & 2 & 4.1 & 3.3 & 0.7 & 1.9 & 1.7 & 0.22 \\
\hline 9300 & 314 & 93 & 156.8 & 43.7 & 5.9 & 1.53 & 4.2 & 3.5 & 0.76 & 2.15 & 1.8 & 0.37 \\
\hline \multicolumn{13}{|c|}{ Profile 21} \\
\hline 211 & 273 & 60.8 & 158.6 & 37.1 & 5.3 & 1.15 & 3.45 & 2.86 & 0.51 & 1.46 & 1.6 & 0.24 \\
\hline 212 & 378 & 64.9 & 254 & 42.3 & 5.7 & 1.24 & 3.75 & 2.8 & 0.53 & 1.35 & 1.51 & 0.24 \\
\hline 214 & 515 & 120.1 & 261.6 & 94.2 & 13.3 & 2.57 & 7.66 & 6.44 & 1.27 & 3.42 & 3.42 & 0.59 \\
\hline 215 & 512 & 115.8 & 256.2 & 98.2 & 13.9 & 2.56 & 8.12 & 6.85 & 1.37 & 3.79 & 4.1 & 0.72 \\
\hline 217 & 346 & 94.1 & 142.2 & 79.2 & 11 & 2.03 & 5.98 & 4.98 & 0.99 & 2.64 & 2.8 & 0.42 \\
\hline 219 & 226 & 57.1 & 104.5 & 46.6 & 6.5 & 1.07 & 3.45 & 2.8 & 0.53 & 1.49 & 1.58 & 0.25 \\
\hline 9221 & 354 & 91.3 & 179.3 & 59.8 & 7.9 & 1.6 & 4.8 & 3.9 & 0.8 & 2.1 & 2.1 & 0.34 \\
\hline \multicolumn{13}{|c|}{ Profile 22} \\
\hline 221 & 829 & 185.6 & 462.9 & 132.6 & 18.5 & 4.9 & 10.85 & 7.18 & 1.3 & 2.99 & 2.02 & 0.27 \\
\hline 222 & 1318 & 263.5 & 727.8 & 242.1 & 34.4 & 9.03 & 19.14 & 11.86 & 2.13 & 4.56 & 2.99 & 0.4 \\
\hline 223 & 925 & 199 & 488.6 & 174.3 & 25 & 6.57 & 13.4 & 9.1 & 1.72 & 3.94 & 2.93 & 0.4 \\
\hline 224 & 1267 & 268.3 & 657.7 & 247.4 & 36.6 & 9.64 & 19.94 & 13.84 & 2.59 & 6.06 & 4.51 & 0.59 \\
\hline 225 & 862 & 184.1 & 362.2 & 216.7 & 33.9 & 10.59 & 19.45 & 15.63 & 3.24 & 8.21 & 6.74 & 0.97 \\
\hline 226 & 969 & 198.4 & 420.8 & 235.8 & 37.1 & 11.54 & 22.86 & 18.98 & 3.89 & 10.04 & 8.04 & 1.15 \\
\hline 229 & 458 & 100.3 & 175.7 & 117.7 & 19.6 & 6.3 & 12.29 & 11.25 & 2.33 & 6.3 & 5.22 & 0.77 \\
\hline 92200 & 592 & 133.2 & 238.9 & 154.9 & 23.4 & 7.2 & 13.05 & 10.1 & 1.96 & 4.91 & 4.01 & 0.56 \\
\hline
\end{tabular}

The fractionation trends of REE from profiles 5 and 22 can also be detected in profile 21 (Fig. 7). Here the divergence between REE patterns of the soil layer, enriched in LREE, and the saprolite, enriched in HREE, is less pronounced but still evident. Local high REE concentrations are bound to weathered mafic minerals (pyroxenes), whereas the bulk of the REE are bound to illite and smectite. 

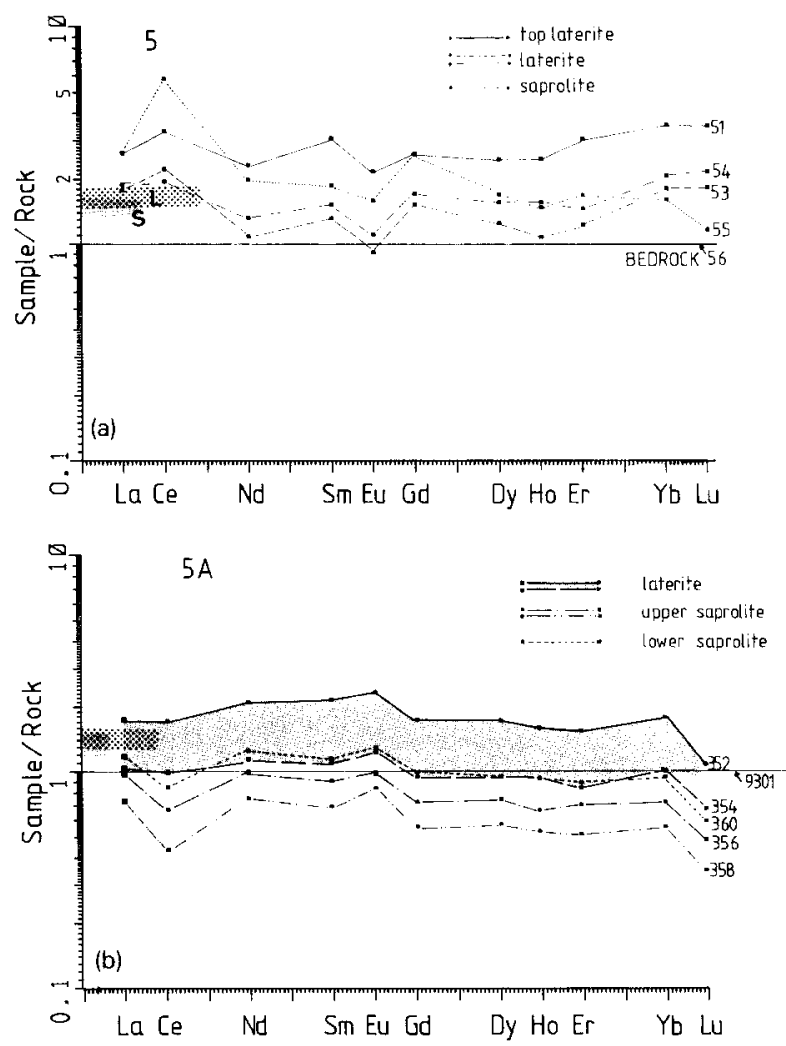

Fig. 5. (a) Fractionation of REE in profile 5 normalized to bedrock; $L$ and $S$ see text. (b) Fractionation of REE in profile $5 \mathrm{~A}$ normalized to bedrock; $\mathrm{L}$ and $\mathrm{S}$ see text.

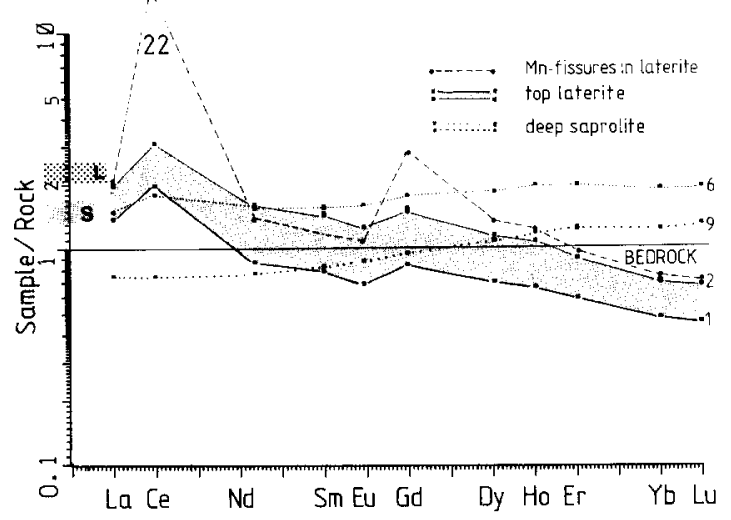

Fig. 6. Fractionation of REE in profile 22 normalized to bedrock; $\mathrm{L}$ and $\mathrm{S}$ see text. 


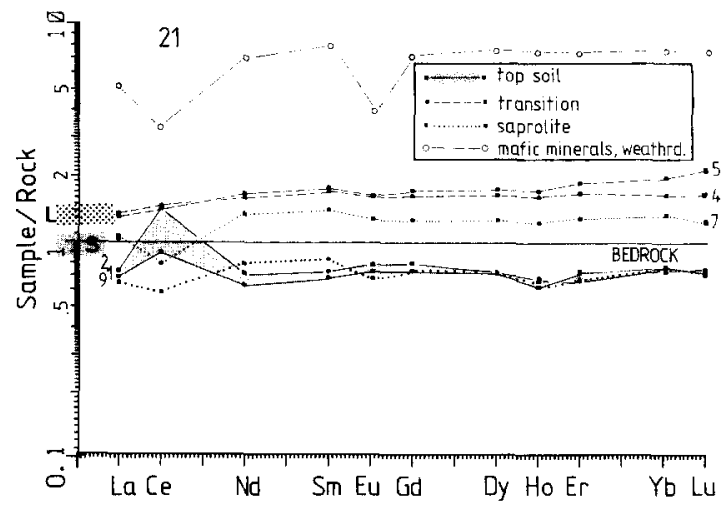

Fig. 7. Fractionation of REE in profile 21 normalized to bedrock; $L$ and $S$ see text.

Under conditions of restricted drainage in profile $4 \mathrm{~A}^{\prime \prime}$, representing TS 4, only Ce shows slight enrichment relative to bedrock wheras all other REE are depleted (Fig. 8). In the sandy-clayey soils of Potiragua, smectite-rich illuvial bottom horizons are significantely less depleted than the eluvial top horizons, where REE are impoverished due to clay mineral lessiviation. In this environment REE are mainly bound to smectite and thus follow the distribution of this mineral. The positive $\mathrm{Ce}$ anomaly is related to the occurrence of manganiferous pisolites.

Fractionation trends of $\mathrm{Eu}$ and $\mathrm{Gd}$ are exempt of further interpretations and conclusions since they show erratic and non interpretable trends, which also may be due to analytical problems.

\subsubsection{Absolute enrichment}

The absolute enrichment of individual REE has been determined by using the Fe content as internal standard. Factors of maximum residual enrichment were established as mean values for the laterite or soil horizons ( $L$ in Figs. 5-8) and for the saprolite horizons ( $\mathrm{S}$ in Figs. 5-8) of the individual profiles. This means that values of the individual REE above/below the limits of maximum residual enrichment,

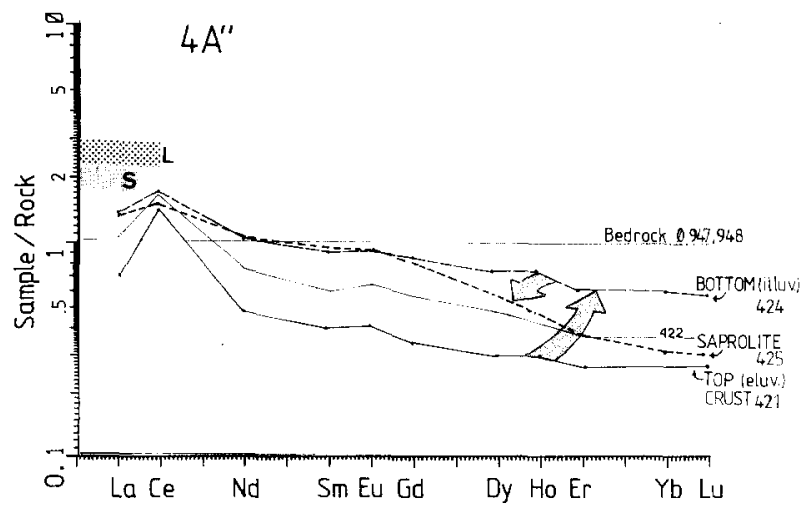

Fig. 8. Fractionation of REE in profile $4 \mathrm{~A}^{\prime \prime}$ normalized to bedrock; $\mathrm{L}$ and $\mathrm{S}$ see text. 
represented by the dotted respectively the shaded bars, indicate absolute supply/ depletion of this element in laterite or soil respectively saprolite. Because of $\mathrm{Fe}$ mobilisation in profiles of TS $4\left(4 \mathrm{~A}^{\prime \prime}\right)$, Ti has been considered the less mobile element and thus was used as internal standard.

In profile 5, all REE are absolutely enriched in the top laterite layer, partly depleted in the intermediate laterite layer and show an absolute gain in the saprolite. In the saprolite of profile 5A, REE are depleted.

In profile 22, Ce shows slight absolute enrichment in the laterite whereas $\mathrm{Er}$-Lu reveal slight absolute gain in the saprolite. The rest of the REE is depleted.

In profile 21, all REE are depleted in the soil layer with exception of $\mathrm{Ce}$, which shows residual behaviour. In the saprolite $\mathrm{Ce}$ is absolutely depleted whereas the rest of the REE, especially the HREE Er-Lu, are absolutely enriched.

In profile 4 the bulk of REE is depleted with increasing intensity towards the HREE and highest depletion in the eluvial horizon. Absolute depletion of $\mathrm{Ce}$ in the upper soil layers may be an artefact caused by the use of $\mathrm{Ti}$ as internal standard. It is assumed that $\mathrm{Ce}$ is also residually enriched in the upper soil layers as in the case of profile 21 .

\section{Discussion of results and conclusions}

The here presented results show a distinct climatic and morphological control of the evolution of weathering profiles as well as of fractionation and enrichment/ depletion of REE.

\subsection{Enrichment and fractionation of $R E E$}

The most significant features of REE behaviour in the weathering profiles are polarisation of LREE and HREE in laterites/soils and saprolites and the Ce anomalies.

- Polarisation of LREE and HREE: During tropical weathering and mineral dissolution, REE are subject to mobilisation and migration. Under slightly acid and oxidizing conditions in upper parts of the weathering profiles, REE are mobilized and transported downward, where the HREE become enriched in the saprolite due to decreasing hydroxide solubility from $\mathrm{Gd}$ to $\mathrm{Lu}$ with increasing alkaline $\mathrm{pH}$ (Nesbitt, 1979). The adsorption of REE to clay minerals like smectite is enhanced with decreasing ionic radii from Gd to Lu (Bonnot-Courtois and Jaffrezic-Renault, 1982). The LREE are removed with exception of $\mathrm{Ce}$, which due to its spontanous oxidation to $\mathrm{Ce}^{4+}$ forms stable compounds in the laterite/soil layers. This process explains the negative $\mathrm{Ce}$ anomaly in the saprolite, since this element is retained in the laterite.

- Ce anomalies: In weathering profiles of SE-Bahia Ce anomalies can be related to two different processes which may overlap eachother.

(i) In the laterite/soil layers, Ce is principally bound to manganiferous, X-ray amorphous concretionary minerals. These concretions are inherited from an earlier phase of profile evolution. During this phase high saturation of solutions in respect to 
Mn and Si had favoured the precipitation of non-stoichiometric Mn oxides in lower parts of the weathering mantle (Formoso et al., 1989; Boulangé et al., 1990). Under these conditions $\mathrm{Ce}$ can be scavenged by $\mathrm{Mn}$ oxides and after oxidation fixed as tetravalent Ce (Rankin and Childs, 1976; Kühnel, 1989; Marker et al., 1991). The stability of $\mathrm{Ce}^{4+}$ compounds such as $\mathrm{Mn}$ oxides or minute cerianite crystals favoured absolute enrichment of $\mathrm{Ce}$ in the weathering products. In consequence of the downward progression of the weathering front, these stable minerals subsequently reached the upper profile parts (laterite/soil layers) as a result of profile truncation during a later phase of profile evolution: during this process stable Ce-bearing concretions from lower profile portions became residually enriched in surface-near profile layers of lateritic respectively kaolinitic composition without being dissolved.

(ii) During weathering of Ce-bearing primary minerals, Ce forms rather immobile compounds and becomes subject to residual enrichment in function of its spontaneous oxidation. Thus it remains residually enriched in the upper part of the profile, causing a negative $\mathrm{Ce}$ anomaly in the saprolite. Ce may be fixed to vermiculite and hydrobiotite, as reported by Duddy (1980). Anomalously high Ce contents of almost $3000 \mathrm{ppm} \mathrm{Ce}_{2} \mathrm{O}_{3}$ in weathered biotites from profiles 5 and 22 confirm this observation (Marker, 1991).

\subsection{Polyphase evolution of the weathering mantle and REE distribution}

The relationship between profile evolution and weathering history on one side and REE distribution and fractionation on the other side may be interpreted as follows:

The weathering products above alkaline rocks in the humid coastal region of SEBahia (profiles 21 and 22) and in Sta. Cruz (profile 5) contain remnants of a former less humid climatic period. These remnants are represented by manganiferous concretions ( $\mathrm{Mn}-\mathrm{Fe}-\mathrm{Si}$ pisolites and veinlets). They have developed in the roots of weathering during an ancient weathering cycle (Phase 1). Similar observations have been made by Sigolo et al. (1987), Trescases et al. (1987) and Formoso et al. (1989) in South Brazil. As described above under (i), the oxide minerals which formed these concretions scavenged and acumulated REE, in paricular Ce.

Climatic changes and less humid conditions in the past are discussed by Conceição et al. (1974), who investigated weathering profiles on granulites in the region of Ilheus, Bahia.

In the formerly even less humid inland regions of Potiragua, the exposure of $\mathrm{Mn}-\mathrm{Fe}-\mathrm{Si}$ rich saprolite zones which was favoured by profile truncation, resulted in the formation of $\mathrm{Mn}-\mathrm{Fe}-\mathrm{Si}$ duricrust cappings. Geomorphological instability caused further profile erosion and the bulk of the eroded material was transported to the coastal plains where important heavy mineral beach placers have developed. The erosional event may also be related to sea level changes during Late Tertiary, as proposed by Gillson (1981).

With the beginning of Pleistocene, climatic conditions became more humid in the coastal regions. Kaolinisation and subordinately lateritisation are the dominating weathering processes which prevailed until today (Phase 2). The weathering front progressed further downward in the truncated weathering profiles, resulting in the 
formation of predominantly kaolinitic-goethitic weathering products. Because of permanently wet conditions in the coastal region, conditions for bauxitisation were never attained (Bardossy and Aleva, 1990).

In the inland regions of Potiragua, restricted weathering conditions in subhumid climate prevailed until recent times. Smectite formation and clay lessiviation are the recent soil forming processes. Degradation of former silica hardcrusts can be observed.

During this phase polarization and fractionation of LREE and HREE took place, being controlled by the prevailing drainage conditions and physico-chemical parameters of weathering as described above.

\subsection{Generalized pattern of REE distribution}

As an attempt to establish a generalized pattern which relates drainage conditions and REE behaviour, the following scheme is presented (Fig. 9):

- Intensive drainage conditions favour enhanced polarization, fractionation and enrichment of REE in a way, that LREE are more intensively depleted in the saprolite and HREE are more strongly depleted in the laterite ( $B$ in Fig. 9). Ce shows considerable positive anomalies in the laterite and HREE are significantly enriched in the saprolite. These features are related to the physico-chemical conditions of well drained profiles: silicate hydrolysis is enhanced, thus liberating considerable amounts of REE to the supergene cycle. Residual enrichment of already existing Ce-bearing

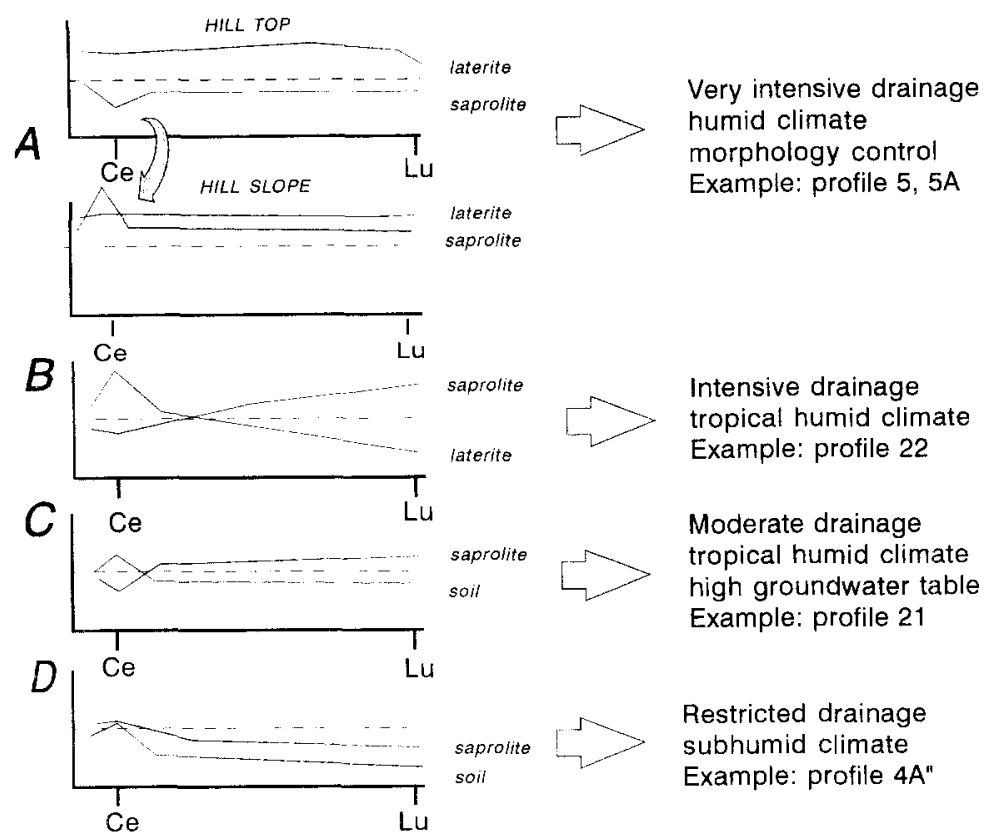

Fig. 9. Relationship between REE fractionation patterns and climatological and morphological parameters. 
minerals like $\mathrm{Mn}$ oxides is favoured by intensive leaching of alkalis and $\mathrm{Si}$, thus causing positive $\mathrm{Ce}$ anomalies in laterite layers. Due to intensive drainage and absence of suitable geochemical barriers like carbonate horizons which could trap La (Fortin, 1989), most LREE are essentially depleted. HREE are intensively leached downward in the profile, retained and absolutely enriched in saprolite zones of low level profiles, where alkaline conditions prevail and smectite is present.

- Less intensive drainage due to permanently elevated groundwater table and/or less humid climate is reflected in weaker fractionation trends and lower enrichment factors of REE ( $\mathrm{C}$ ind Fig. 9).

- Under restricted drainage conditions silicate hydrolysis is impeded and REE liberation, mobilisation and fractionation are limited. Ce remains in the weathering products as stable $\mathrm{Ce}^{4+}$ compound whereas the remaining $\mathrm{REE}$, mainly the HREE, are depleted. This depletion is due to the fact that clay minerals which preferentially fix HREE, are subject to lessiviation (D in Fig. 9). Furthermore precipitation of secondary silica in soil and saprolite has a dilution effect on all REE, thus explaining relative Ce depletion.

- Morphological control on REE behaviour is documented in profiles 5 and 5A ( $\mathrm{A}$ in Fig. 9). The considerable enrichment of $\mathrm{Ce}$ in saprolites of the hill slope (profile 5) is related to its strong depletion in hill top position (profile $5 \mathrm{~A}$ ). Here $\mathrm{Ce}$ shows depletion along the entire profile. In this case intensive drainage along the hilltop and -slope is believed to be responsible for Ce mobilisation and transportation in form of $\mathrm{Ce}^{3+}$ in ground- and porewaters under less oxidizing or even reducing conditions. These processes have been observed by Braun et al. (1990) in lateritic profiles. The possibility of long lateral Ce transport has already been discussed by Marker et al. (1991). Remobilisation of $\mathrm{Ce}$ from surface near laterite layers under oxidizing conditions is more difficult to explain. However, Beauvais et al. (1987) discuss the dissolution of of stable $\mathrm{MnO}_{4}$ (pyrolusite) and mobilisation of $\mathrm{Mn}$ under supergene conditions. The strong depletion of $\mathrm{Ce}$ in the laterite layer of profile $5 \mathrm{~A}$ thus may be explained by dissolution of stable manganiferous scavenger minerals and subsequent transport of $\mathrm{Ce}$ in colloidal solution.

Concluding, REE distributions may yield valuable indications for profile evolution and paleoenvironment. It is evident that tropical weathering leads to considerable modification of REE fractionation patterns. With increasing weathering intensity and drainage conditions, REE fractionation becomes more pronounced. Important supergene REE concentrations can only be expected in regions with intensive lateritic weathering, existence of geochemical barriers and abundance of scavenger minerals in weathering profiles.

In SE-Bahia the bulk of the REE is retained in the weathering products whereas LREE show tendencies of removal from the weathering mantles and transport to the sea. This result is confirmed by observations of Goldstein and Jacobsen (1988), who stated that river and sea waters in the tropics have negative REE anomalies. 


\section{Acknowledgements}

The first author wishes to thank the Deutsche Forschungsgemeinschaft and the Conselho Nacional de Desenvolvimento Ciêntífico e Tecnológico (CNPq) in Brazil for support the research presented here in the form of research grants in Brazil.

\section{References}

Bardossy, G. and Aleva, G.J.J., 1990. Lateritic Bauxites. Dev. Econ. Geol., 27. Elsevier, Amsterdam, 624 pp.

Beauvais, A., Melfi, A., Nahon, D. and Trescases, J.J., 1987. Petrologie du gisement lateritique manganesifere d'Azul (Bresil). Miner. Dep., 22: 124-134.

Bonnot-Courtois. C., 1981. Geochimie des terres rares dans les principaux milieux de formation et de sedimentation des argiles. Unpublished Diss., Univ. Orsay, $215 \mathrm{pp}$.

Bonnot-Courtois, C. and Jaffrezic-Renault. N.. 1982. Etudes des echanges entre terres rares etcations interfoliaires de deux argiles. Clay Miner., 17: 409-420.

Boulangé, B., Muller, J.P. and Sigolo, J.B., 1990. Behaviour of the Rare Earth Elements in a lateritic bauxite from syenite. Chem. Geol., 84: 350-351.

Braun. J.J., Pagel, M., Muller, J.P., Bilong, P., Michard, A. and Guillet, B., 1990. Cerium anomalies in lateritic profiles. Geochim. Cosmochim. Acta, 54: 781-795.

Conceicao, T.M.L., Moniz, A.C., Oliveira, J.J. and Sieffermann, G., 1974. Les sols a montmorrillonite sur gneiss de la zone tropicale humide de l'etat de Bahia. Signification paleoclimatique. Cah. ORSTOM, Ser. Pedologie, Vol. XII, No. 2, pp. 137-143.

Cordani, U., Bernat, M. Teixeira, W. and Kinoshita, H., 1974. Idades radiometricas de rochas alcalinas do sul da Bahia. In: Anais 28. Congr. Bras. Geọl., Porto Alegre, Vol. 6, pp. 253--259.

Duddy, I.R., 1980. Redistribution and fractionation of rare-earth and other elements in a weathering profile. Chem. Geol., 30: $363-381$.

Formoso, M.L.L., Retzmann, K. and Valeton, I.. 1989. Fractionation of Rare Earth Elements in weathering profiles on phonolites in the area of Lages, S.C., Brazil. Geochim. Bras., 3(1): 51 . 62.

Fortin, P. 1989. Mobilisation, fractionnement et accumulation des terres rares lors de l' alteration lateritique de sediments argilo-sableux du bassin de Curitiba (Bresil). Ecole des Mines de Paris, Mem. de Sci. de la Terre, No. 10, 186 pp.

Gillson, J.L., 1981. Geologia dos placeres Brasilieiros de ilmenita. Rev. Eng. Min. Metall., 33(197): 231 241.

Goldstein, S.J. and Jacobsen, S.B., 1988. Rare earth elements in river waters. Earth Plane1.. Sci. Lett., 89: $35-47$.

Kronberg. B.I., Tazaki, K. and Melfi, A.J., 1987. Detailed geochemical studies of the initial stages of weathering of alkaline rocks, Ilha de Sao Sebastiao, Brazil. Chem. Geol., 60: 79-88.

Kuhnel, R.A., 1989. the role of cationic and anionic scavengers in laterites. Chem. Geol., 60: $31-40$.

Marker, A., 1991. Lateritische Verwitterung von Alkaligesteinen in SE-Bahia, Brasilien. Abschlußbericht des DFG-Forschungsvorhabens, $103 \mathrm{pp}$.

Marker, A., Friedrich, G. Carvalho, A. and Melfi, A., 1991. Control of the distribution of Mn, Co. Zn, Zr, $\mathrm{Ti}$ and REEs during the evolution of lateritic covers above ultramafic complexes. J: Geochem. Explor., 40: $361-383$.

Melfi, A.J. and Carvalho. A.. 1983. Bauxitization of alkaline rocks in Southern Brazil. Sci. Geol. Mem.. 73 : $161-172$.

Nesbitt, H.W., 1979. Mobility and fractionation of rare earth elements during weathering of a granodiorite. Nature, 279: 206-210.

Rankin, P.C. and Childs, C.W., 1976. Rare-earth elements in iron-manganese concretions from some New Zealand soils. Chem. Geol., 18: $55 \cdots 64$.

Schellmann, W.. 1982. Eine neue Lateritdefinition. Geol. Jb., $58: 31 \ldots 47$. 
Sigolo, J.B., Boulange, B., Muller, J.P. and Schmitt, J.M., 1987. Distribuicao de elementos terras raras em um perfil de bauxita lateritica sobre rocha alkalina - Macico de Passa Quatro (MG). In: W. Wildner (Editor), Proc. 1. Congr. Bras. Geoquim., Porto Alegre. SGBq, Rio de Janeiro, Vol. 1, pp. 71--81.

Trescases. J.J.. Fortin, P., Melf, A.J. and Nahon, D., 1987. Rare earth element accumulation in lateritic weathering of Pliocene sediments, Curitiba, Basin (Brazil). In: R. Rodrigues-Clemente and Y. Tardy (Editors), Geochemistry of the Earth Surface and Processes of Mineral Formation. Proc. of Conf. Geochemistry of the Earth Surface and Processes of Mineral Formation. Granada, 1986. Consejo Superior de Investigaciones Científicas, Madrid, pp. $259-272$. 